\title{
Oxidative Stress is the Principal Contributor to Inflammasome Activation in Retinal Pigment Epithelium Cells with Defunct Proteasomes and Autophagy
}

\author{
Niina Piippo Eveliina Korhonen $^{\mathrm{a}}$ Maria Hyttia Kati Kinnunen ${ }^{\mathrm{b}, \mathrm{c}}$ \\ Kai Kaarniranta ${ }^{\mathrm{b}, \mathrm{c}} \quad$ Anu Kauppinen $^{\mathrm{a}}$ \\ aSchool of Pharmacy, University of Eastern Finland, Kuopio, bepartment of Ophthalmology, Institute \\ of Clinical Medicine, University of Eastern Finland, Kuopio, 'Department of Ophthalmology, Kuopio \\ University Hospital, Kuopio, Finland
}

\section{Key Words}

Nlrp3 inflammasome $•$ Activation mechanism $•$ Potassium efflux $•$ Cathepsin B $\bullet$ ROS

\begin{abstract}
Background/Aims: Previously, we demonstrated that blockade of the intracellular clearance systems in human retinal pigment epithelial (RPE) cells by MG-132 and bafilomycin A1 (BafA) induces NLRP3 inflammasome signaling. Here, we have explored the activation mechanisms behind this process. NLRP3 is an intracellular receptor detecting factors ranging from the endogenous alarmins and adenosine triphosphate (ATP) to ultraviolet radiation and solid particles. Due to the plethora of triggers, the activation of NLRP3 is often indirect and can be mediated through several alternative pathways. Potassium efflux, lysosomal rupture, and oxidative stress are currently the main mechanisms associated with many activators. Methods: NLRP3 inflammasomes were activated in human RPE cells by blocking proteasomes and autophagy using MG-132 and bafilomycin $A 1$ (BafA), respectively. $P_{2} X_{7}$ inhibitor A740003, potassium chloride $(\mathrm{KCl})$, and glyburide, or $\mathrm{N}$-acetyl-L-cysteine (NAC), ammonium pyrrolidinedithiocarbamate (APDC), diphenyleneiodonium chloride (DPI), and mito-TEMPO were added to cell cultures in order to study the role of potassium efflux and oxidative stress, respectively. IL-1 $\beta$ was measured using the ELISA method. ATP levels and cathepsin $B$ activity were examined using commercial kits, and ROS levels using the fluorescent dye $2^{\prime}, 7^{\prime}$-dichlorodihydrofluorescein diacetate (DCFDA). Results: Elevated extracellular potassium prevented the priming factor IL-1 $\alpha$ from inducing the production of reactive oxygen species (ROS). It also prevented IL-1 $\beta$ release after exposure of primed cells to MG-132 and BafA. Inflammasome activation increased extracellular ATP levels, which did not appear to trigger significant potassium efflux. The activity of the lysosomal enzyme, cathepsin B, was reduced by MG-132 and BafA, suggesting that cathepsin B was not playing any role in this phenomenon.
\end{abstract}




\section{Cellular Physiology Cell Physiol Biochem 2018;49:359-367 \\ \begin{tabular}{ll|l} 
DOI: 10.1159/000492886 & $\begin{array}{l}\text { O 2018 The Author(s). Published by S. Karger AG, Basel } \\
\text { wwww.karger.com/cpb }\end{array}$ \\
\hline Published online: 23 August, 2018
\end{tabular} \\ Cells}

Instead, MG-132 triggered ROS production already 30 min after exposure, but treatment with antioxidants blocking NADPH oxidase and mitochondria-derived ROS significantly prevented IL-1 $\beta$ release after this activating signal. Conclusion: Our data suggest that oxidative stress strongly contributes to the NLRP3 inflammasome activation upon dysfunctional cellular clearance. Clarification of inflammasome activation mechanisms provides novel options for alleviating pathological inflammation present in aggregation diseases, such as age-related macular disease (AMD) and Alzheimer's disease.

(C) 2018 The Author(s)

Published by S. Karger AG, Basel

\section{Introduction}

Nucleotide-binding domain and Leucine-rich repeat Receptor containing a Pyrin domain 3 (NLRP3) is an intracellular pattern-recognition receptor (PRR) capable of forming a structure called the inflammasome [1]. An assembly of the protein complex containing NLRP3 receptors which are connected to the caspase-1 enzyme through the adaptor protein apoptosis-associated speck-like protein containing CARD (ASC) results in the caspase-1mediated cleavage of two pro-inflammatory cytokines IL-1 $\beta$ and IL-18 into their mature forms that can then be released from the cell [1]. Almost any danger signal ranging from extreme temperatures to solid particles can trigger the NLRP3 oligomerization and the subsequent formation of the inflammasome [2]. Due to the plethora of stimulants, the activation of NLRP3 is mainly indirect with three leading mechanisms having been associated with the process i.e. potassium efflux, lysosomal destabilization, and the generation of reactive oxygen species (ROS).

Potassium leakage from the cell can be triggered in at least three different ways; 1 ) by extracellular adenosine triphosphate (ATP) that activates ATP-gated ion channels, 2) by membrane-permeating molecules, such as bacterial toxins that form pores through the cell membrane, or 3) by high extracellular $\mathrm{Ca}^{2+}$ levels [3-7]. Lysosomal destabilization has been associated with many NLRP3 activators such as monosodium urate (MSU) crystals, asbestos, alum, and silica, which are taken up into cells via phagocytosis [8, 9]. Incomplete (frustrated) phagocytosis causes lysosomal rupture and the release of the lysosomal enzyme, cathepsin B, which has been shown capable of activating NLRP3 [10, 11]. Since NLRP3 activators generally have several effects on the cell, it has also been postulated that particulate matter and other agents potentially rupturing the lysosomal membrane could induce potassium efflux, which would then serve as the ultimate activator of NLRP3 [7]. In addition to its effect on potassium efflux, ATP is also capable of inducing both cathepsin B release and oxidative stress $[12,13]$. Particle phagocytosis has also been shown to induce an NADPH oxidasemediated ROS production; if this phenomenon can be prevented, then the inflammasome does not become activated [9]. In addition to NADPH oxidase activity, mitochondria are another major ROS source in the cells since in these organelles, ROS are generated as byproducts of ATP-producing oxidative phosphorylation. Disturbances in the mitochondrial electron transport chain increase ROS production; for example, this has been shown to predispose macrophages to inflammasome activation after their exposure to ATP $[14,15]$. In summary, these examples emphasize that NLRP3 has multiple activation mechanisms and many of them seem to be highly dependent on local conditions.

In this study, we have explored the activation mechanism of NLRP3 in our aggregation model utilizing human retinal pigment epithelial (RPE) cells where the blockade of proteasomes and autophagy is known to induce inflammasome signaling [16]. Post-mitotic RPE cells, that play the critical role in the pathogenesis of age-related macular degeneration (AMD), share various features with the role of neurons in Alzheimer's disease. Considering the crucial role of the NLRP3 inflammasome in both health and disease, understanding the activation process is essential if we are to consider this structure as a potential therapeutic target. 


\section{Cellular Physiology Cell Physiol Biochem 2018;49:359-367 \begin{tabular}{ll|l} 
and Biochemistry Published online: 23 August, 2018 & $\begin{array}{l}\text { (c) } 2018 \text { The Author(s). Published by S. Karger AG, Basel } \\
\text { www.karger.com/cpb }\end{array}$
\end{tabular} \\ Piippo et al.: Oxidative Stress Activates Inflammasomes in Retinal Pigment Epithelium Cells}

\section{Materials and Methods}

\section{Cells and stimulations}

Majority of this study has been performed on human ARPE-19 line cells that are adequately available for all necessary repetitions in order to verify the findings with certainty. The inflammasome activation has been achieved by blocking intracellular degradation systems using our previously optimized protocol [16]. In this model, proteasomes and autophagy are blocked by MG-132 and bafilomycin A1 (BafA), respectively. BafA has also been replaced by chloroquine with similar results [16]. Since the model set up, we have proven that this protocol is working also on primary human RPE cells and RPE cells differentiated from human embryonal stem cells (hESC-RPE cells; data not shown).

ARPE-19 cells were purchased from the American Type Culture Collection (ATCC, Manassas, VA, USA). The cells were cultured in standard conditions of humidified $5 \% \mathrm{CO}_{2}$ atmosphere at $37{ }^{\circ} \mathrm{C}$ in Dulbecco's modified Eagle's medium (DMEM) and nutrient mixture F-12 1:1 mixture (Life Technologies, Carlsbad, CA, USA) containing 10\% inactivated fetal bovine serum (FBS; Thermo Fisher Scientific, Waltham, MA, USA), 100 units/ml penicillin, $100 \mu \mathrm{g} / \mathrm{ml}$ streptomycin, and $2 \mathrm{mM} \mathrm{L-glutamine} \mathrm{(Lonza,} \mathrm{Basel,} \mathrm{Switzerland).} \mathrm{In} \mathrm{the}$ experiments, cells were plated on 12-well plates (Sigma-Aldrich, St. Louis, MO, USA) at a concentration of 200000 cells/ml/well in serum-containing medium and incubated for three days. Confluent cell cultures were washed with serum-free medium and primed with recombinant human IL-1 $\alpha$ ( $4 \mathrm{ng} / \mathrm{ml}$; R\&D Systems, Minneapolis, NE, USA) in serum-free medium. After $24 \mathrm{~h}$ incubation, the cells were exposed to MG-132 ( $5 \mu \mathrm{M}$; Calbiochem) for $24 \mathrm{~h}$. The cells were further stimulated with bafilomycin A1 (BafA, $50 \mathrm{nM}$; SigmaAldrich) for an additional $24 \mathrm{~h}$. Cell cultures were also exposed to the $\mathrm{P}_{2} \mathrm{X}_{7}$ inhibitor A740003 (50 $\mu \mathrm{M}$; Santa Cruz Biotechnology, Dallas, TX, USA) or $50 \mathrm{mM} \mathrm{KCl}$ (potassium chloride) simultaneously with IL-1 $\alpha$. $\mathrm{N}$-acetyl-L-cysteine (10 mM; NAC), ammonium pyrrolidinedithiocarbamate (50 $\mu \mathrm{M}$; APDC), or glyburide $(200 \mu \mathrm{M})$ were added 5 min prior to MG-132, and mito-TEMPO $(200 \mu \mathrm{M})$ or diphenyleneiodonium chloride (20-30 $\mu$ M; DPI; all from Sigma-Aldrich) $1 \mathrm{~h}$ before MG-132 where indicated.

Test conditions, such as concentrations and incubation times, were optimized separately for each chemical prior to experiments reported here. MG-132+BafA is known to cause some damage to the plasma membrane, which can be seen as increased release of lactate dehydrogenase (LDH) [16] but the cells still remain functional and the factors measured from medium have not entered there through passive leakage. In addition to our unpublished data, it can be seen in our previous publication that e.g. the levels of IL-1 $\beta$ were significantly different when measured either from the cell lysates or the culture medium samples [16]. In case of severely ruptured membranes, the concentrations would have remained closer to each other.

\section{Sample preparation}

Medium samples and cell lysates were collected $24 \mathrm{~h}$ after the BafA treatment. Cells were rinsed with 1x Dulbecco's phosphate buffered saline (DPBS; Lonza) before lysis with the specific buffer for the cathepsin $B$ activity assay (Abnova). The cell lysates were centrifuged (16 $060 \mathrm{x} \mathrm{g,} 10 \mathrm{~min}$ ) and supernatants were transferred into clean microtubes. Protein concentrations were measured by the Bradford method from cell lysates [17]. Both medium samples and cell lysates were stored at $-70 \stackrel{\circ}{ } \mathrm{C}$ until analyzed.

\section{Enzyme-linked immunosorbent assay (ELISA) measurements}

Concentrations of the pro-inflammatory cytokine IL-1 $\alpha$ were determined using a commercial ELISA set (BD, Franklin Lakes, NJ, USA). The assay was performed from the cell culture medium samples as described previously [16]. We have optimized the ELISA kit to detect lower IL-1 $\beta$ concentrations than reported by the manufacturer. We have verified our protocol by comparing the results to those obtained using the eBioscience $^{\mathrm{TM}}$ human IL-1beta High Sensitivity ELISA (eBioscience, San Diego, CA, USA), and the assay functionality has persevered highly constant and repeatable. We have also shown that this assay measures mature IL-1 $\beta$ rather than inactive pro-IL-1 $\beta[16]$

\section{ATP measurement}

Extracellular ATP was measured from cell culture medium samples using a commercial kit (ATP Determination Kit, Thermo Fisher Scientific) according to the manufacturer's protocol. 


\section{Cellular Physiology Cell Physiol Biochem 2018;49:359-367 \\ \begin{tabular}{ll|l} 
and Biochemistry & $\begin{array}{l}\text { DOI: 10.1159/000492886 } \\
\text { Published onlıne: } 23 \text { August, } 2018\end{array}$ & $\begin{array}{l}\text { (c) } 2018 \text { The Author(s). Published by S. Karger AG, Basel } \\
\text { www.karger.com/cpb }\end{array}$ \\
\hline Piippo et al: Oxidative Stress Activates Inflammasomes in Retinal Pigment Epithelium
\end{tabular} \\ Cells}

\section{Cathepsin B activity assay}

Cathepsin B activity was measured from cell lysates with commercial kits (R\&D Systems and Abnova, respectively) according to the manufacturers' protocol. Results were normalized to protein concentrations.

\section{ROS detection}

Cells were plated on 96-well plates (Corning, NY, USA) at a concentration of 20000 cells/well in 0.1 $\mathrm{ml}$ of serum-containing medium, and incubated for two days. Confluent cell cultures were exposed for $24 \mathrm{~h}$ to IL-1 $\alpha(4 \mathrm{ng} / \mathrm{ml})$ and $\mathrm{KCl}(50 \mathrm{mM})$ in serum-free medium where indicated. Thereafter, $5 \mu \mathrm{M} \mathrm{MG}-132$ and $10 \mu \mathrm{M}$ ROS-sensitive fluorescent dye 2',7'-dichlorodihydrofluorescein diacetate (DCFDA; Thermo Fisher Scientific) were added to the cultures for $0.5,1$, or $2 \mathrm{~h}$. After incubation at $+37^{\circ} \mathrm{C}$ and $5 \% \mathrm{CO}_{2}$, the cell culture medium was removed, the cells were washed once with DPBS (Gibco), and fresh DPBS was added. Intracellular ROS production was measured using a spectrofluorometer (Cytation 3, Biotek Instruments Inc, Winooski, USA) with an excitation $\lambda$ of $485 \mathrm{~nm}$ and emission $\lambda$ of $530(\mathrm{ex} / \mathrm{em}=485 / 530 \mathrm{~nm})$.

\section{Statistical analysis}

Statistical analyses were conducted using the GraphPad Prism (Graphpad Software, San Diego, CA). Pairwise comparisons were performed using the Mann-Whitney $U$-test and $p$-values of 0.05 or less were considered significant. In cases the relative differences wanted to be emphasized, the data of treated cells have been compared to the mean of their most relevant control group.

\section{Results}

Potassium efflux does not play a major role in the inflammasome activation by MG$132+$ BafA

Since the activation of ATP-gated cation channels can result in potassium efflux, we first measured the levels of extracellular ATP from our cell culture medium samples. An exposure of IL-1 $\alpha$-primed ARPE-19 cells separately to either MG-132 or BafA showed increasing (after MG-132) and decreasing (after BafA) trends in the levels of extracellular ATP. When administered together, they significantly increased the amounts of extracellular ATP (Fig. 1). This finding pointed to the possibility that ATP could promote potassium efflux-mediated NLRP3 activation by opening ATP-sensitive $\mathrm{K}^{+}$channels. However, inhibition of the potassium channel/ATP receptor $\mathrm{P}_{2} \mathrm{X}_{7}$ by the specific inhibitor $\mathrm{A} 740003$ did not significantly reduce the levels of IL-1 $\beta$ cytokine released from the MG-132 and BafA-treated RPE cells (Fig. 2A), suggesting that $\mathrm{P}_{2} \mathrm{X}_{7}$ was unlikely to mediate potassium efflux for activating the inflammasome. The result was similar also with glyburide, a functional inhibitor of ATP-sensitive potassium channels $\left(\mathrm{K}_{\text {ATP }}\right)$, which previously has been shown to inhibit NLRP3 inflammasome-mediated signaling [18, 19] (Fig. 2B). Furthermore, when we elevated the extracellular potassium levels (with $\mathrm{KCl}$ ), i.e. a property that should be capable of preventing potassium efflux being induced by any means, this also failed to reduce the MG-132+BafA-induced IL-1 $\beta$ production in IL-1 $\alpha$-primed ARPE-19 cells (Fig. 2C). Although ATP is a widely known and strong inflammasome activator in macrophages, we have not been able to repeat that on RPE cells (data not shown). Numerous different possibilities have been tested but trials still need to be continued. Together, these suggest that ATP is not at least as obvious inflammasome activator in RPE cells as it is in macrophages, and the role of potassium efflux may not be the principal mechanism in the inflammasome activation upon dysfunctional cleanup.
Fig. 1. The levels of extracellular ATP in the culture medium following the inflammasome activation of IL- $1 \alpha$ primed RPE cells by MG132+bafilomycin A (BafA). Data combined from 3 independent experiments with 4-6 replicate samples/group in each experiment are presented as mean \pm SEM. ${ }^{* *} \mathrm{p}<0.01$, Mann - Whitney U-test.

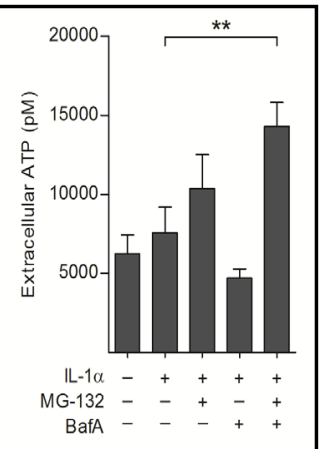

KARGER 


\section{Cellular Physiology \begin{tabular}{ll|l} 
and Biochemistry & $\begin{array}{l}\text { DOI: 10.1159/000492886 } \\
\text { Published online: 23 August, } 2018\end{array}$ & $\begin{array}{l}\text { (c) } 2018 \text { The Author(s). Published by S. Karger AG, Basel } \\
\text { www.karger.com/cpb }\end{array}$
\end{tabular} \\ Piippo et al.: Oxidative Stress Activates Inflammasomes in Retinal Pigment Epithelium Cells}

Fig. 2. The effect of potassium efflux blockade on the release of IL- $1 \beta$ cytokine from ARPE-19 cells upon the inflammasome activation. Possible potassium leakage from cells was prevented by inhibiting ATP-sensitive ion channels using a $\mathrm{P}_{2} \mathrm{X}_{7}$ inhibitor (A) or by glyburide (B). Moreover, $\mathrm{K}+$ efflux was blocked by increasing the extracellular level of potassium by $\mathrm{KCl}$ (C). IL- $1 \alpha$ released from the cells was measured from medium samples

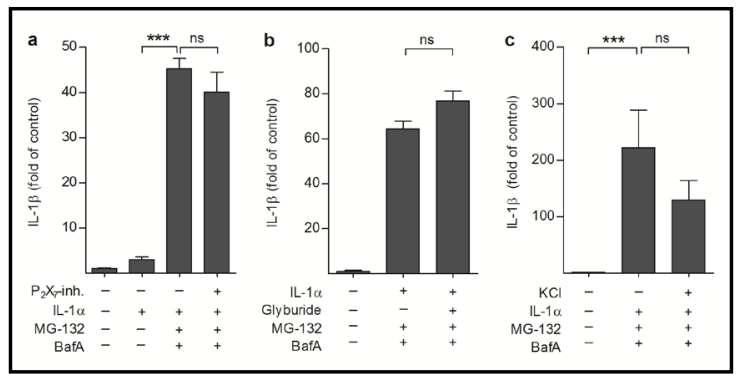
using the ELISA technique. Data combined from 2-8 independent experiments with 4-8 replicate samples/group in each experiment are presented as mean \pm SEM. ${ }^{* * *} \mathrm{p}<0.001$, ns - not significant, Mann -Whitney U-test.

Cathepsin $B$ does not contribute to the inflammasome activation by $M G-132$ and BafA

The possible role of lysosomal enzyme cathepsin B in the NLRP3 activation was evaluated by measuring the cathepsin $B$ activity from cell lysates. IL- $1 \alpha$ alone did not affect the cathepsin $B$ activity but the exposure of ARPE-19 cells to MG-132 and BafA significantly reduced the enzyme's activity i.e. cathepsin B activity in treated cells was only $12.7 \%$ from that of untreated control cells (Fig. 3). Concurrently, the IL$1 \beta$ release from the cells was significantly increased (Figs. 1-2). Therefore, active cathepsin B which has been associated with the NLRP3 activation in other systems (10, 11), did not appear to be the mechanism in our set-up.

Challenges in intracellular clearance promote ROS production in human RPE cells

We observed in our previous study that the MG-132+BafA treatment significantly increased oxidative stress by upregulating the intracellular levels of the lipid peroxidation end product, 4-hydroxynonenal (HNE) [16]. Since MG132 is already capable of inducing the inflammasome activation in primed RPE cells and BafA merely potentiates the response, the production of short-living ROS was studied right after the addition of the first activating signal (MG-132). We determined intracellular ROS production by adding DCFDA to cell cultures concomitantly with MG-132, and followed the ROS levels for two hours. We observed that MG-132 induced significant ROS production already $30 \mathrm{~min}$ after the proteasome inhibition (Fig. 4A). The increase in ROS levels proceeded until $1 \mathrm{~h}$ but did not increase further after that (Fig. 4A). MG-132 induced ROS production also in unprimed cells (Fig. 5). The result is in accordance with our previous data showing inflammasome activation by MG-132 and BafA without IL- $1 \alpha$ priming (16). Interestingly, the priming of RPE cells with IL- $1 \alpha$ significantly increased the ROS production (Fig. 4B). Conversely, a high extracellular $\mathrm{K}^{+}$level that prevented potassium efflux from the cells, significantly reduced the ROS production of IL- $1 \alpha$-treated ARPE-19 cells (Fig. 4B). MGin ARPE-19 cells upon the inflammasome activation. Data combined from 3 independent experiments with 1-3 replicate samples/group in each experiment are presented as mean \pm SEM. ${ }^{*} \mathrm{p}<0.05$, Mann -Whitney U-test.
Fig. $\quad 4$. Intracellular R $\quad \mathrm{O} \quad \mathrm{S}$ production. ROS were detected at different mopoints the MG-132
treatment of primed ARPE-19 cells (A). Additionally, the effect of high extracellular potassium levels on the ROS production at $1 \mathrm{~h}$ was studied (B). Data combined from 5-7 independent experiments with 5-8 replicate samples/group in each experiment are presented as mean \pm SEM. ${ }^{*} \mathrm{p}<0.05,{ }^{* * *} \mathrm{p}<0.001$, ns - not significant, Mann -Whitney U-test.

Fig. 3. Cathepsin B activity 


\section{Cellular Physiology \begin{tabular}{ll|l} 
and Biochemistry & $\begin{array}{l}\text { DOI: 10.1159/000492886 } \\
\text { Published online: 23 August, } 2018\end{array}$ & $\begin{array}{l}\text { O 2018 The Author(s) } \\
\text { www.karger.com/chb }\end{array}$ \\
\cline { 2 - 3 }
\end{tabular} \\ Piippo et al.: Oxidative Stress Activates Inflammasomes in Retinal Pigment Epithelium \\ Cells}

Fig. 5. ROS production by MG-132 in unprimed ARPE-19 cells. Cells were grown until confluent (initially 20000 cells/well on a 96 well plate), and DCFDA (10 $\mathrm{uM}$ ) was added with MG-132 (5 uM) following the incubation for $1 \mathrm{~h}$ before the detection by a fluorometer (ex488nm/em528nm). Data combined from 3 independent experiments with 12 or 24 parallel samples per group are presented as mean \pm SEM. ${ }^{* * *}$ p $<0.001$, Mann-Whitney U-test.

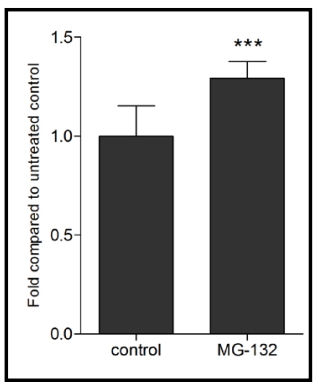

Fig. 6. The role of ROS in the IL-1 $\beta$ release induced by MG-132 and BafA. Intracellular ROS were inhibited with NAC, APDC (A), DPI (B), or mito-TEMPO (C), and IL- $1 \beta$ was measured from the culture medium using the ELISA technique. Data combined from 2-3 independent experiments with 4-6 parallel samples per group are presented as mean \pm SEM. ${ }^{*} \mathrm{p}<0.05,{ }^{* *} \mathrm{p}<0.01,{ }^{* * *} \mathrm{p}<0.001$, ns $=$ not significant, Mann-Whitney U-test.
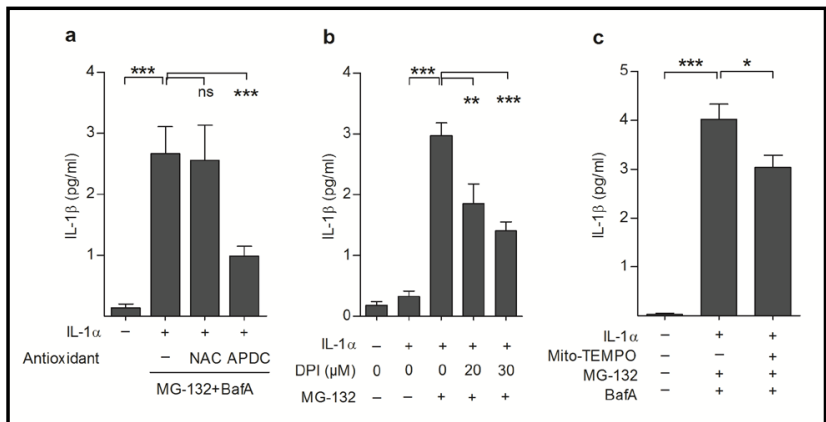

132 restored the ROS production to a similar level as detected with IL-1 $\alpha$ alone but did not achieve the significantly increased ROS levels induced by MG-132 in primed cells without the presence of high extracellular potassium (Fig. 4B). These data suggest that potassium effluxinduced ROS production may play a role in the priming of RPE cells by IL- $1 \alpha$.

\section{Antioxidants reduce the $I L-1 \beta$ secretion from $M G-132$ and BafA-treated RPE cells}

In order to study the role of ROS in NLRP3 activation, we applied ROS scavengers NAC and APDC to cell cultures for reducing the oxidative stress. Treatment with the glutathione precursor NAC did not result in any change in the MG-132+BafA-induced IL-1 $\beta$ release; in contrast APDC, an inhibitor of NADPH oxidase significantly reduced the levels of extracellular IL-1 $\beta$ (Fig. 6A). The role of NADPH oxidase-dependent ROS production in the IL- $1 \beta$ release was confirmed by treatment with DPI, another inhibitor of NADPH oxidase-derived ROS (Fig. 6B). A significant decrease in the IL-1 $\beta$ release was obtained also by the mitochondrial ROS scavenger mito-TEMPO (Fig. 6C). These data are considered evidence that both NADPH oxidase and mitochondria-derived ROS contribute to the IL-1 $\beta$ secretion in our aggregation model.

\section{Discussion}

In the present study, we found that oxidative stress was the major mechanism contributing to the NLRP3 inflammasome activation in human RPE cells exposed to MG132 and BafA, two compounds which together block the intracellular clearance of protein aggregates and dysfunctional organelles. NAC is a synthetic precursor of glutathione (GSH) that serves as a substrate for ROS-scavenging enzymes [20]. In human breast cancer cells, NAC has been shown to inhibit the effects of several proteasome inhibitors including MG132 [21]. Despite its dual role as an antioxidant and a proteasome inhibitor blocker, NAC displayed the least efficacy on the IL-1 $\beta$ release in our model when compared to other antioxidative molecules. DPI has been reported to block both NADPH oxidase and mitochondriaderived ROS but with respect to the latter, DPI concentrations should be higher than those $(20-30 \mu \mathrm{M})$ used in our studies $[22,23]$. However, in order to exclude the possibility that DPI would be affecting also the mitochondria-derived ROS in our system, e.g. due to cell- 
Piippo et al.: Oxidative Stress Activates Inflammasomes in Retinal Pigment Epithelium Cells

dependent differences between macrophages and RPE cells, we also used APDC, another inhibitor of NADPH oxidase-derived ROS. Since both inhibitors caused similar effects, we conclude that the NADPH oxidase pathway in addition to mitochondria-derived ROS is participating in the inflammasome activation evoked by MG-132 and BafA.

Bauernfeind et al. reported that in macrophages, ROS were important in the priming but not in the activation of NLRP3 inflammasome [23]. Interestingly, we observed that 50 $\mathrm{mM}$ extracellular $\mathrm{KCl}$ (i.e. a concentration that prevents potassium leakage from the cell), blocked the ROS production induced by the priming signal IL-1 $\alpha$. This suggests that IL$1 \alpha$-induced potassium efflux-linked ROS production can promote the NLRP3 priming also in human RPE cells. Under these conditions, MG-132 and BafA did not result in increased IL-1 $\beta$ release, which may be a consequence of incomplete priming. In a study with bonemarrow derived mouse macrophages (BMDMs), ROS were not needed either for priming or for the activation of NLRP3 by bacterial toxins, particulate matter, or ATP [7]. Instead, the researchers considered potassium efflux to be the common factor responsible for the NLRP3-mediated signaling. Guha et al. have provided data that BzATP could result in IL-1 $\beta$ release from RPE cells by binding to $\mathrm{P}_{2} \mathrm{X}_{7}$ receptors [24]. In our system, the inhibition of ATPdependent ion channels exerted no effect on the IL- $1 \beta$ release, suggesting that IL- $1 \alpha$ may have induced potassium leakage by some means other than through ATP-gated channels. Our results also indicated that IL- $1 \alpha$ alone did not increase the levels of extracellular ATP. This supports the idea that ATP release rather followed than preceded the inflammasome signaling. In contrast to the study of Bauernfeind et al. [23], in our present study, it was clear that ROS were playing a central role in the inflammasome activation process. This became evident when ROS scavengers were added after the priming signal. Thereby, our data is also in line with the numerous studies indicating that increased oxidative stress is a mechanism capable of achieving NLRP3 activation [14, 15, 25-27].

Since elevated ROS production can result in the permeabilization of lysosomal membranes [28], and lysosomal rupture has been shown to activate NLRP3 inflammasomes in ARPE-19 cells [29], we also examined this possibility. It appears that the presence of cathepsin B is not enough but its enzymatic activity is needed for NLRP3 activation [10,11, 30]. However, Hornung et al. showed in mouse macrophages treated with silica crystals that cathepsin B activity and caspase-1 activity do not exist at the same time [10]. They suggested that the loss of cathepsin B activity after the lysosomal rupture rapidly activated caspase- 1 . Our results are in line with that hypothesis, since we observed significantly reduced enzyme activity despite the inflammasome activation. The loss of enzymatic activity was not surprising since MG-132 and BafA are both known to inactivate or prevent the activation of cathepsin B [31-33].

NLRP3 is an intracellular pattern recognition receptor (PRR) with complicated activation mechanisms due to the diverse nature of its activators and its apparent propensity for indirect ligand sensing instead of direct contact and recognition. In this study, we found oxidative stress to be the predominant mechanism in the NLRP3 activation process in human RPE cells with impaired intracellular clearance. This resembles the situation in the RPE cells of patients with age-related macular degeneration (AMD), which is the most common vision-threatening disease of the elderly in Western countries [34, 35]. Chronic, low level inflammation is involved in the pathogenesis of AMD and recently, NLRP3 inflammasome signaling has been implicated as having a crucial role in this process [27, 36-38]. Clarifying the activation mechanisms of NLRP3 will represent a major step forward in leading to novel treatments for chronic inflammation-related diseases such as AMD.

\section{Acknowledgements}

We warmly acknowledge Dr. Ewen MacDonald for the language revision, and Res. Dir. Emeritus Antero Salminen for his valuable collaboration, discussions, and critical review of the manuscript. This study was financially supported by Päivikki ja Sakari Sohlberg 


\section{Cellular Physiology Cell Physiol Biochem 2018;49:359-367 \begin{tabular}{ll|l} 
DOI: 10.1159/000492886 & $\begin{array}{l}\text { O 2018 The Author(s). Published by S. Karger AG, Basel } \\
\text { www.karger.com/cpb }\end{array}$ \\
\hline
\end{tabular} \\ Piippo et al.: Oxidative Stress Activates Inflammasomes in Retinal Pigment Epithelium Cells}

Foundation, Finnish Eye Foundation, Finnish Cultural Foundation (Central and North-Savo Regional Fund), Orion-Farmos Research Foundation, the Alfred Kordelin Foundation, Emil Aaltonen Foundation, Kuopio University Hospital (VTR funding), and the Academy of Finland (Health Research Council projects AK297267, AK307341, and KK5503743).

\section{Disclosure Statement}

The authors declare no conflict of interests.

\section{References}

1 Martinon F, Mayor A, Tschopp J: The inflammasomes: guardians of the body. Annu Rev Immunol 2009;27:229-265.

-2 Schroder K, Zhou R, Tschopp J: The NLRP3 inflammasome: a sensor for metabolic danger? Science 2010;327:5963:296-300.

-3 Perregaux D, Gabel CA: Interleukin-1 beta maturation and release in response to ATP and nigericin: Evidence that potassium depletion mediated by these agents is a necessary and common feature of their activity. J Biol Chem 1994;269:15195-15203.

4 Solle M, Labasi J, Perregaux DG, Stam E, Petrushova N, Koller BH, Griffiths RJ, Gabel CA: Altered cytokine production in mice lacking P2X(7) receptors. J Biol Chem 2001;276:125-132.

5 Mariathasan S, Weiss DS, Newton K, McBride J, O’Rourke K, Roose-Girma M, Lee WP, Weinrauch Y, Monack DM, Dixit VM: Cryopyrin activates the inflammasome in response to toxins and ATP. Nature 2006;440:228232.

6 Petrilli V, Papin S, Dostert C, Mayor A, Martinon F, Tschopp J: Activation of the NALP3 inflammasome is triggered by low intracellular potassium concentration. Cell Death Differ 2007;14:1583-1589.

7 Munoz-Planillo R, Kuffa P, Martinez-Colon G, Smith BL, Rajendiran TM, Nunez G: K(+) efflux is the common trigger of NLRP3 inflammasome activation by bacterial toxins and particulate matter. Immunity 2013;38:1142-1153.

-8 Martinon F, Petrilli V, Mayor A, Tardivel A, Tschopp J: Gout-associated uric acid crystals activate the NALP3 inflammasome. Nature 2006;440:237-241.

-9 Dostert C, Petrilli V, Van Bruggen R, Steele C, Mossman BT, Tschopp J: Innate immune activation through Nalp3 inflammasome sensing of asbestos and silica. Science 2008;320:674-677.

10 Hornung V, Bauernfeind F, Halle A, Samstad EO, Kono H, Rock KL, Fitzgerald KA, Latz E: Silica crystals and aluminum salts activate the NALP3 inflammasome through phagosomal destabilization. Nat Immunol 2008;9:847-856.

11 Halle A, Hornung V, Petzold GC, Stewart CR, Monks BG, Reinheckel T, Fitzgerald KA, Latz E, Moore KJ, Golenbock DT: The NALP3 inflammasome is involved in the innate immune response to amyloid-beta. Nat Immunol 2008;9:857-865.

12 Cruz CM, Rinna A, Forman HJ, Ventura AL, Persechini PM, Ojcius DM: ATP activates a reactive oxygen species-dependent oxidative stress response and secretion of proinflammatory cytokines in macrophages. J Biol Chem 2007;282:2871-2879.

13 Lopez-Castejon G, Theaker J, Pelegrin P, Clifton AD, Braddock M, Surprenant A: P2X(7) receptor-mediated release of cathepsins from macrophages is a cytokine-independent mechanism potentially involved in joint diseases. J Immunol 2010;185: 2611-2619.

$\checkmark 14$ Zhou R, Yazdi AS, Menu P, Tschopp J: A role for mitochondria in NLRP3 inflammasome activation. Nature 2011;469:221-225.

15 Nakahira K, Haspel JA, Rathinam VA, Lee SJ, Dolinay T, Lam HC, Englert JA, Rabinovitch M, Cernadas M, Kim HP, Fitzgerald KA, Ryter SW, Choi AM: Autophagy proteins regulate innate immune responses by inhibiting the release of mitochondrial DNA mediated by the NALP3 inflammasome. Nat Immunol 2011;12:222-230.

-16 Piippo N, Korkmaz A, Hytti M, Kinnunen K, Salminen A, Atalay M, Kaarniranta K, Kauppinen A: Decline in cellular clearance systems induces inflammasome signaling in human ARPE-19 cells. Biochim Biophys Acta 2014;1843:3038-3046. 


\section{Cellular Physiology Cell Physiol Biochem 2018;49:359-367 \begin{tabular}{ll|l} 
and Biochemistry & $\begin{array}{l}\text { DOI: 10.1159/000492886 } \\
\text { Published onlIne: 23 August, } 2018\end{array}$ & $\begin{array}{l}\text { () 2018 The Author(s). Published by S. Karger AG, Basel } \\
\text { www.karger.com/cpb }\end{array}$ \\
\hline
\end{tabular}}

Piippo et al.: Oxidative Stress Activates Inflammasomes in Retinal Pigment Epithelium Cells

17 Bradford MM: A rapid and sensitive method for the quantitation of microgram quantities of protein utilizing the principle of protein-dye binding. Anal Biochem 1976;72:248-254.

-18 Lamkanfi M, Mueller JL, Vitari AC, Misaghi S, Fedorova A, Deshayes K, Lee WP, Hoffman HM, Dixit VM: Glyburide inhibits the Cryopyrin/Nalp3 inflammasome. J Cell Biol 2009;187:61-70.

-19 Kerur N, Hirano Y, Tarallo V, Fowler BJ, Bastos-Carvalho A, Yasuma T, Yasuma R, Kim Y, Hinton DR, Kirschning CJ, Gelfand BD, Ambati J: TLR-independent and P2X7-dependent signaling mediate Alu RNAinduced NLRP3 inflammasome activation in geographic atrophy. Invest Ophthalmol Vis Sci 2013;54:73957401.

20 Sun SY: N-acetylcysteine, reactive oxygen species and beyond. Cancer Biol Ther 2010;9:109-110.

-21 Halasi M, Wang M, Chavan TS, Gaponenko V, Hay N, Gartel AL: ROS inhibitor N-acetyl-L-cysteine antagonizes the activity of proteasome inhibitors. Biochem J 2013;454:201-208.

-22 Hancock JT, Jones OT: The inhibition by diphenyleneiodonium and its analogues of superoxide generation by macrophages. Biochem J 1987;242:103-107.

23 Bauernfeind F, Bartok E, Rieger A, Franchi L, Nunez G, Hornung V: Cutting edge: reactive oxygen species inhibitors block priming, but not activation, of the NLRP3 inflammasome. J Immunol 2011;187:613-617.

24 Guha S, Baltazar GC, Tu L, Lim JC, Eysteinsson T, Laties AM, Mitchell CH: P2X7 receptor stimulation raises lysosomal pH and triggers cytokine release from RPE cells. FASEB J 2011;25:1 Supplement:906.2-906.2.

25 Zhou R, Tardivel A, Thorens B, Choi I, Tschopp J: Thioredoxin-interacting protein links oxidative stress to inflammasome activation. Nat Immunol 2010;11:136-140.

26 Martinon F: Signaling by ROS drives inflammasome activation. Eur J Immunol 2010;40:616-619.

-27 Kauppinen A, Niskanen H, Suuronen T, Kinnunen K, Salminen A, Kaarniranta K: Oxidative stress activates NLRP3 inflammasomes in ARPE-19 cells-Implications for age-related macular degeneration (AMD). Immunol Lett 2012;147:29-33.

-28 Boya P, Kroemer G: Lysosomal membrane permeabilization in cell death. Oncogene 2008;27:6434-6451.

-29 Tseng WA, Thein T, Kinnunen K, Lashkari K, Gregory MS, D’Amore PA, Ksander BR: NLRP3 Inflammasome Activation in Retinal Pigment Epithelial Cells by Lysosomal Destabilization: Implications for Age-Related Macular Degeneration. Invest Ophthalmol Vis Sci 2013;54:110-120.

30 Brandstetter C, Mohr LK, Latz E, Holz FG, Krohne TU: Light induces NLRP3 inflammasome activation in retinal pigment epithelial cells via lipofuscin-mediated photooxidative damage. J Mol Med (Berl) 2015;93:905-916.

31 Longva KE, Blystad FD, Stang E, Larsen AM, Johannessen LE, Madshus IH: Ubiquitination and proteasomal activity is required for transport of the EGF receptor to inner membranes of multivesicular bodies. J Cell Biol 2002;156:843-854.

32 Lee S, Sato Y, Nixon RA: Lysosomal proteolysis inhibition selectively disrupts axonal transport of degradative organelles and causes an Alzheimer's-like axonal dystrophy. J Neurosci 2011;31:7817-7830.

-33 Brojatsch J, Lima H, Kar AK, Jacobson LS, Muehlbauer SM, Chandran K, Diaz-Griffero F: A proteolytic cascade controls lysosome rupture and necrotic cell death mediated by lysosome-destabilizing adjuvants. PLoS One 2014;9:e95032.

-34 Kaarniranta K, Sinha D, Blasiak J, Kauppinen A, Vereb Z, Salminen A, Boulton ME, Petrovski G: Autophagy and heterophagy dysregulation leads to retinal pigment epithelium dysfunction and development of agerelated macular degeneration. Autophagy 2013;9:973-984.

-35 Taylor DJ, Hobby AE, Binns AM, Crabb DP: How does age-related macular degeneration affect real-world visual ability and quality of life? A systematic review. BMJ Open 2016;6:e011504-2016-011504.

-36 Tarallo V, Hirano Y, Gelfand BD, Dridi S, Kerur N, Kim Y, Cho WG, Kaneko H, Fowler BJ, Bogdanovich S, Albuquerque RJ, Hauswirth WW, Chiodo VA, Kugel JF, Goodrich JA, Ponicsan SL, Chaudhuri G, Murphy MP, Dunaief JL, Ambati BK, Ogura Y, Yoo JW, Lee DK, Provost P, Hinton DR, Nunez G, Baffi JZ, Kleinman ME, Ambati J: DICER1 loss and Alu RNA induce age-related macular degeneration via the NLRP3 inflammasome and MyD88. Cell 2012;149:847-859.

37 Doyle SL, Campbell M, Ozaki E, Salomon RG, Mori A, Kenna PF, Farrar GJ, Kiang AS, Humphries MM, Lavelle EC, O'Neill LA, Hollyfield JG, Humphries P: NLRP3 has a protective role in age-related macular degeneration through the induction of IL-18 by drusen components. Nat Med 2012;18:791-798.

-38 Kauppinen A, Paterno JJ, Blasiak J, Salminen A, Kaarniranta K: Inflammation and its role in age-related macular degeneration. Cell Mol Life Sci 2016;73:1765-1786. 